\title{
Focusing on culture-related episodes in a teletandem interaction between a Brazilian and an American student
}

\author{
Maisa A. Zakir, Ludmila B. A. Funo \& João A. Telles
}

To cite this article: Maisa A. Zakir, Ludmila B. A. Funo \& João A. Telles (2016) Focusing on culture-related episodes in a teletandem interaction between a Brazilian and an American student, Innovation in Language Learning and Teaching, 10:1, 21-33, DOI: 10.1080/17501229.2016.1134861

To link to this article: https://doi.org/10.1080/17501229.2016.1134861

\section{Published online: 16 Feb 2016.}

\section{Submit your article to this journal $\Longleftarrow$}

Џlll Article views: 240

View Crossmark data ¿ 


\title{
Focusing on culture-related episodes in a teletandem interaction between a Brazilian and an American student
}

\author{
Maisa A. Zakir, Ludmila B. A. Funo and João A. Telles \\ Centro de Línguas e Desenvolvimento de Professores, Universidade Estadual Paulista, Assis, SP, Brazil
}

\begin{abstract}
Teletandem is a telecollaborative learning context that involves pairs of native (or competent) speakers of different languages interacting through voice, text and webcam image. Using Skype, each participant plays the role of learner for half an hour, speaking and practising the language of his/her partner. This paper focuses on a teletandem interaction between a female Brazilian and a male American undergraduate student. We aim to analyse how the participants approach the cultural dimension in a teletandem interaction. In the first part, we present five perspectives on the concept of culture (Levy, 2007. "Culture, Culture Learning and New Technologies: Towards a Pedagogical Framework." Language Learning and Technology 11 (2): 104127). We also adopt a new discourse construct presented by Zhu (2012. "Weaving Language and Culture Together: the Process of Culture Learning in a Chinese as a Foreign Language Classroom." PhD diss., University of lowa) from the term coined by Swain and Lapkin (1998. "Interaction and Second Language Learning: Two Adolescent French Immersion Students Working Together." Modern Language Journal 82 (3): 320-337), 'language-related episodes' and analyse five 'culture-related episodes'. We define 'culture-related episode' as any segment of a dialogue produced during teletandem sessions in which students focus on any interest, explanation or inquisitiveness about their own or their partner's culture. Our findings provide evidence that the exchanges between people from different nationalities and life experiences engender many possibilities of understanding culture in its various dimensions. Finally, we suggest that further research on learning languages and cultures should be developed to better understand the complexity and the characteristics of online telecollaborative contexts.
\end{abstract}

\section{ARTICLE HISTORY}

Received 18 May 2014

Accepted 8 November 2015

\section{KEYWORDS}

Teletandem; language learning; cultural learning; culture-related episode

\section{Introduction}

Language education has undoubtedly been impacted by the use of information and communication technology, which has allowed the development of both asynchronous and synchronous activities through the computer. According to Belz (2003), in her classical definition, 'telecollaboration involves the application of global computer networks to foreign (and second) language learning and teaching in institutionalized settings'. More recently, the term Online Interaction and Exchange has also been used in a more general way to refer to the use of technology in language education (Dooly and O'Dowd 2012).

Currently a great number of institutions around the world develop telecollaboration projects ${ }^{1}$, which aim at promoting intercultural contact among language learners. The project Teletandem 
Brasil: foreign languages for all ${ }^{2}$ has been developed since 2006 at UNESP (São Paulo State University) in Brazil. Teletandem Brasil matches up Brazilian university students who wish to learn a foreign language with students in other countries who are learning Portuguese. The pairs of native (or competent) speakers of different languages work collaboratively by using Skype resources of voice, text and webcam images in order to learn the language of the other. Each student plays the role of learner for half an hour by speaking and practising the language of his partner, and then they switch roles and languages. It is a virtual and collaborative language learning context that has three main theoretical principles: languages must not be mixed; teletandem partners should share the same amount of time as they use the target language; the learning process is autonomous (Brammerts 2003; Vassallo and Telles 2006).

Doctoral dissertations on teletandem (Cavalari 2009; Furtoso 2011; de Garcia 2010; Kaneoya 2008; Luvizari-Murad 2011; Vassallo 2010) have offered evidence that this context is propitious for both language and culture learning, although the focus is on language in most of these (e.g. the expression 'target culture' appears in Vassallo's data analysis, 2010, indicating that deepening one's understanding of a foreign culture can be considered a main goal by teletandem partners rather than improving foreign language skills). Such evidence as well as the institutionalization of the partnerships has broadened the perspectives of the Teletandem Brasil project, which, in its current phase, is entitled Teletandem and Transculturality ${ }^{3}$. The project now aims at investigating the cultural dimension, the nature, the structures and the processes of these video interactions, particularly in the fields of education for intercultural communication in foreign languages and of education for global citizenship (Telles and Ferreira 2011).

This paper focuses on a teletandem interaction between two undergraduate students in order to explore evidence of cultural learning in a teletandem session. In the first part, grounded in Kramsch (1998) and Levy (2007), we present five dimensions of the concept of culture to which we refer in the analysis. Additionally, we propose a unit of analysis for interpreting the data - the culture-related episode (CRE), which has been adapted from Swain and Lapkin's (1998) term, language-related episodes ${ }^{4}$. Finally we encourage further research on learning of languages and cultures within online collaborative contexts in order to better understand them.

\section{Teletandem and culture: definitions and dimensions}

The notion of culture has been widely discussed in the scope of language teaching. Different methodologies and approaches consider culture as part of the process of learning a language. According to Kumaravadivelu (2008), although culture has been an integral part of language education, it was only with the spread of international commerce and communication following World War II that the necessity of teaching culture explicitly was recognized. Before that, culture was considered a byproduct and not an important part of the curriculum.

According to Kumaravadivelu (2008), the 1990s are also considered a turning point in the policies and practices of teaching culture. As part of this change of emphasis, in 1996 the American Council on the Teaching of Foreign Languages published the National Standards, in which culture starts to be seen not as an additional skill to be taught in class, but as an element as important as the traditionally valued aspects like grammar and vocabulary. In the American document, culture is understood as the integration of three inter-related components: 'the philosophical perspectives, the behavioural practices, and the products - both tangible and intangible - of a society' (National Standards 1996, 47).

The Common European Framework of Reference for Languages (CEFR) also highlights the relation between language and culture by postulating that plurilingualism has to be seen in the context of pluriculturalism. This implies that language is more than a major aspect of culture; it is a means of access to cultural manifestations (Council of Europe 2001, 6). In the CEFR, plurilingual and pluricultural competence is understood as 'the ability to use languages for the purposes of communication and to 
take part in intercultural interaction, where a person, viewed as a social agent has proficiency, of varying degrees, in several languages and experience of several cultures'. (Council of Europe 2001, 168).

The idea that guides the understanding of culture in the CEFR can be found in the fifth chapter of the document. The cultural component relates to sociocultural knowledge (everyday living, living conditions, interpersonal relations, values, beliefs and attitudes, body language, social conventions and ritual behaviour) and intercultural awareness (understanding of the relation - similarities and distinctive differences - between the 'world of origin' and the 'world of the target community') (Council of Europe 2001, 102-103).

Michael Byram's concept of intercultural communicative competence is another milestone in the growing importance of thinking about the role of culture in language education. To Byram $(2000,10)$,

[...] someone with some degree of intercultural competence is someone who is able to see relationships between different cultures - both internal and external to a society - and is able to mediate, that is interpret each in terms of the other, either for themselves or for other people. It is also someone who has a critical or analytical understanding of (parts of) their own and other cultures - someone who is conscious of their own perspective, of the way in which their thinking is culturally determined, rather than believing that their understanding and perspective is natural.

Although this paper does not aim at identifying or assessing the participants' intercultural competence, it is important to consider it as long as in the globalized world people have been more and more in contact with situations in which they have to show some understanding of their own or others' culture(s). As the American Council on Education (ACE) points out, 'in spite of an apparent growing national interest in international education, relatively few undergraduates gain international or intercultural competence in college' (Deardorff 2004, 15). Thus, focusing on culture in language education is a way to shed light on this problem, especially in telecollaboration projects, which have promoted virtual intercultural contact (Kramsch and Uryo 2014; Telles 2015) among people from different parts of the world.

As we can see, and as Goodfellow and Lamy (2009) argue, the concept of culture is undoubtedly complex and may have different perspectives. In this paper, we consider five dimensions of culture as described by Levy (2007) because they broaden the understanding of this concept: (a) culture as elemental; (b) culture as relative; (c) culture as group membership; (d) culture as contested and (e) culture as individual (variable and multiple). Besides that, like Levy (2007), who presents projects in which the use of technology is associated with culture teaching and learning, we also focus on foreign language teaching mediated by technology (teletandem).

Following Levy (2007), we consider the classical definition of Kramsch $(1998,10)$, for whom 'culture can be defined as membership in a discourse community that shares a common social space and history, and common imaginings'. Levy $(2007,105)$ considers that 'culture is both a manifestation of a group, or a community, and of an individual's experience within it, or apart from it. As a group, members engage with one another in a shared social space'. Such space may not be only physical, but also virtual, as in the context of teletandem interactions.

Teletandem involves two speakers of different languages, who may frequently represent different discourse communities and also have individual characteristics that emerge in their dialogues. Thus, the five aspects of culture as presented by Levy may be considered appropriate to the object of analysis of this paper because they are broad enough to accommodate all the dimensions that will be analysed in our account of CREs.

As we were able to verify, all these dimensions can be identified in teletandem interactions. Thus each one of them will be briefly presented in the next section, aiming to provide evidence of the ways in which they can be discerned in our object of study. It is important to clarify that, although the dimensions are described separately, as Levy (2007) explains, the concept of culture is essentially holistic in nature and each dimension overlaps and builds upon the one before. 


\subsection{Culture as elemental}

In this perspective, cultural orientation begins at birth. This means that people grow and learn certain systems of values and beliefs, even if they are not aware of that. From the moment we are born, contact with people and with the world helps us shape our identities, attitudes, emotions, values and beliefs. Hence, this dimension acknowledges that the foreign language learner is not culturally a 'blank slate', but brings concepts, stereotypes and expectations as speaker of a certain mother tongue.

According to Levy $(2007,106)$, 'The notion of projecting values and a frame of reference has been recognized in foreign language teaching, and perhaps most especially in teaching English as a foreign language'. In teletandem interactions, in which most students help the partner to learn their native language, the conception of culture as elemental may be observed. It may affect the ways in which learners understand and interpret the foreign language from their own orientation and cultural experiences.

\subsection{Culture as relative}

This dimension considers culture as a relative rather than absolute concept. In other words, a different culture is understood in contrast with one's own culture. Analysing Lo Bianco and Crozet's (2003) book on teaching culture, Levy concludes that 'Making generalisations is central in this approach: in other words, the belief that what we do and what they do is common to all, across the two respective cultures being compared' (Levy 2007, 107, emphasis added).

These characteristics observed in teletandem interactions seem to be at the root of problems associated with the contrastive approach in learning and teaching a second culture. In order to minimize these generalizations it would be necessary to 'focus on the properties of individuals or character types rather than cultures at large' (Guest 2002, cited in Levy 2007). Such focus could be applied to the teletandem context. Teacher-mediators of teletandem sessions can raise students' awareness of and attention to this kind of contrast that often leads to generalizations. Both teletandem practitioners and teacher-mediators should take Guest's suggestion of focus into account and reflect upon their individual characteristics as well as on those they share with other members of the cultural groups to which they belong.

\subsection{Culture as group membership}

In this dimension, culture is understood as a way of participating in a certain speech community and as related to group identification, which may occur in different ways, such as geographical location, political view, sexual orientation, religion, clothing, food and so forth. According to Levy $(2007,108)$, age, profession, sports, language and other shared aspects and activities may also delimit cultures, to the extent that this is possible in the transcultural world we live in nowadays (see Welsch 1999). However, teletandem remains an online context in which participants can talk about cultures and identify themselves with them in latent or obvious ways.

When introducing culture as group membership within a context of language teaching, Levy (2007) presents the following question raised by Guest (2002): 'Do members of the culture really want foreigners to master and display the internal nuances of that culture?' Reporting on a study carried out by Hinkel (1996), Levy (2007) adds that 'even though students recognized pragmalinguistic norms of the target culture, they were not always willing to follow them' (Levy 2007, 109).

Although teletandem is not the context of language teaching and learning to which these authors were referring, such identification issues may also be found in teletandem interactions. We notice that participants frequently try to find something in common with their partners abroad. This can be interpreted as a need, or willingness, to identify with one another in order to get 'closer' and make the interaction more pleasant and friendly. 
A possible reason why this identification occurs may be explained by the fact that:

Cultures as groups adopt particular practices and norms of behaviour, sometimes involving explicit or implicit rules and codes of conduct. One becomes a member of the culture not only by notionally agreeing to its practices, or simply by participating in them, but by being accepted by the membership. (Levy 2007, 109)

Nevertheless, recognizing these attempts at identification does not mean that differences and disagreements do not sometimes emerge between the partners. In many cases, trying to find something in common between the respective cultures is the starting or arrival point to the contrasts, as we will verify later in the analysis.

\subsection{Culture as contested}

This dimension is usually associated with the term 'culture shock', which may be related to both the individual level and a broader scale. In the first case, according to Levy's (2007) concept, culture shock is related to the individual's own experience, when s/he has contact with another culture by travelling or learning a foreign language. In such situations, one's values and systems of beliefs may be contested. This explains why 'learning a language can be such a profound (and worthwhile) experience, because one's core beliefs and values may be challenged, reoriented and reset' (Levy 2007, 110).

In the second case, and still according to Levy (2007), cultures may be contested also on a broad scale, that is, culture shock is related not to individual experiences but to collective ones. Quoting Levy $(2007,109)$ 'cultures may be contested at the level of the nation state or beyond, for example when a "clash of cultures" is proclaimed in the media'.

Students bring along their expectations and representations about the partner's culture to their first teletandem meeting. This is evident in the dialogues. In the interaction analysed below, our data may not be enough to assert whether there is a clash of cultures between the partners; but if it is not a confrontation, it is at least some sort of inquisitiveness about certain cultural practices that are discussed during the interaction.

Thus, even though the participants seek a conciliatory tone and focus on the differences between their respective cultures (mostly as a learning process), it is important to consider this dimension of culture as contested, in the sense that

culture is closely related to the dynamics of power and produces asymmetries in the ability of individuals and groups to define and achieve their goals. Furthermore culture is also an arena of struggle and contradiction, and there is no one culture in the homogeneous sense. On the contrary, there are dominant and subordinate cultures that express different interests and operate from different and unequal terrains of power. (Giroux 1988, cited in Levy 2007, 110)

The asymmetries and misunderstandings between teletandem partners may be noticed in their discourse and reveal either the dominance or the subordination of the respective cultures.

\subsection{Culture as individual (variable and multiple)}

This dimension postulates that each individual's interpretation of culture is variable and subjective. Likewise, in the teletandem context participants will have individual interpretations of the partner's and their own culture. The way culture is interpreted is modified by factors like 'world knowledge, experience living abroad, political awareness and so forth' (Levy 2007, 111)

This dimension seems essential to the teletandem context, since cultures are presented from one person's perspective, and most often teletandem partners share individual experiences.

Thus, when an individual is in a position to represent their own culture, either as a language teacher or learner, their interpretation will be subjective and personal. In addition, new cultural understandings that arise from cultural contact and exchange will similarly be subject to individual interpretation. (Levy 2007, 111) 
However, there are some ways of minimizing the subjectivity of this dimension of culture as individual. The access to other sources of information and the experience of living abroad and/or contacting people in foreign countries are examples of that. After all, our interpretations are not static, and they may be modified as we engage in these transcultural experiences. In other words, when observing or participating in an interactive exchange, interpretations of a language and/or culture can differ from learner to learner. Consequently, each teletandem interaction will produce different interpretations of both partner's cultures.

\section{Methodology}

The two students on whom this study focuses are Gabi and Will ${ }^{5}$. She is Brazilian, her major was Languages and Literatures and she studied English and French as a foreign language. She had been to Portugal in a university exchange programme. Will is American, his major was International Relations and he studied Portuguese and Spanish as a foreign language. The interaction took place in the first semester of 2011 and Gabi was substituting for Will's customary partner, who was absent from the class that day. In total, he participated in five interactions and the one in which he talked with Gabi was the third.

We transcribed the 52-minute long audio-visual recording (Windows Media Player audio/video file) between Gabi and Will, following simple systematization criteria, adapted from Marcuschi (1986). Since the purpose of this article is to analyse how the students approach the cultural dimension in a teletandem interaction, the transcription of a whole session may provide plausible evidence of the students' engagement in discussing culture. During the analysis we focused on how cultural meanings were discursively constructed in interaction.

In this paper, our data show that culture is one of the topics that the students approach in the teletandem session. Thus, we use as a unit of analysis the term culture-related episodes, defined as any part of a dialogue produced in the teletandem sessions in which the students focus on any interest, explanation or inquisitiveness about their own culture or the partner's.

Our study's interpretive horizon is Levy's (2007) reflection about culture. This means that we take these theoretical constructs as a starting point and not a final one. We aim to foster new reflections about culture not only in the teletandem context but also in other telecollaboration projects.

\section{Analysis}

In the recording, we identify a total of seven culture-related episodes divided into the following themes: (a) soccer; (b) music genres; (c) lifestyles and social practices; (d) weather; (e) accents; (f) academic life; (g) politics and economy. In this article we analyse five of them because they are representative of the various dimensions through which culture can be interpreted in this specific teletandem interaction.

The first excerpt is a culture-related episode in which the teletandem partners talk about soccer. This topic emerged after Will had said he would come back to Brazil for the World Cup because, in his opinion, watching soccer games in South America is a 'much more intense experience'.

\begin{tabular}{lll}
\hline 46 & Will: & I will! World Cup, I will come back! \\
47 & Gabi: & Yes, World Cup? \\
48 & Will: & Copa do Mundo, yeah! \\
49 & Gabi: & Oh, yes. Ok. So, it's very good. Do you like football? \\
50 & Will: & Yeah, I do. I definitely like to watch it. I really ... I mean, I like watching it in South America, because \\
51 & & it's so much ... more intense ... everybody is ... uh ... more into it! They're excited about it. Yeah ... \\
52 & Gabi: & I love football! \\
53 & Will: & That's great! \\
54 & Gabi: & Yes, but ... but I don't understand anything. \\
55 & Will: & (Laughs) \\
56 & Gabi: & but I love ... \\
\hline
\end{tabular}




\section{Excerpt 1: transcription of teletandem partners' multimodal interaction}

The American partner's response may show at least two dimensions of culture, as presented by Levy (2007): culture as elemental and culture as relative.

It involves the former in the sense that Will, by stating that he likes watching soccer games in South America, projects a set of his own socio-historical values on this virtual interaction and on his Brazilian partner. He may believe that, for Gabi, soccer is a pre-existing and/or pre-designated artefact (see Pennycook 2004) that is valuable for a young woman born in Brazil as part of her cultural experiences.

Will so much considers soccer as a pre-existing and pre-designated artefact to Brazilian people that, without any negotiation, he immediately grasps the meaning of 'football' for 'soccer', when Gabi asks him 'Do you like football?' (I. 49).

Will uses the phrase 'everybody is more into it [soccer]!' (I. 51). This can be interpreted as a generalization coming from a cultural imaginary that may have been constructed by Will's contact with many different socio-historical instances (as media, interpersonal relationships and many other lifelong experiences assimilated by Will). Possibly he generalizes people from South America as 'more into it', because of his experiences in Brazil and Argentina. These can evoke the other cultural dimension mentioned above: culture as relative, since it is grounded on the comparisons between one's own culture (American, in Will's case) and the partner's ('South American' - Brazilian and Argentinian).

Will also establishes what he sees as a difference between 'watching soccer in North America and watching soccer in South America'. For him, watching soccer games in South America is a much more intense experience. Will makes an explicit comparison.

At the beginning of this analysis, we said that the first excerpt represents a culture-related episode in which at least two dimensions of culture (Levy 2007) could be interpreted (elemental and relative). However, a more careful analysis of the same excerpt can also disclose other dimensions: culture as individual. Will's utterance triggers his own interpretation of the importance of soccer in the South American scene; and culture as group membership. Will's utterance presupposes an understanding of soccer as the cultural construct of a group to which Gabi demonstrates that she belongs - a group of soccer lovers (I. 52).

In the next excerpt, the teletandem partners are talking about country music. This part of the dialogue emerged from Gabi's use of the word 'caipira' (countryperson, 'redneck'), and Will asked her where she had come from.

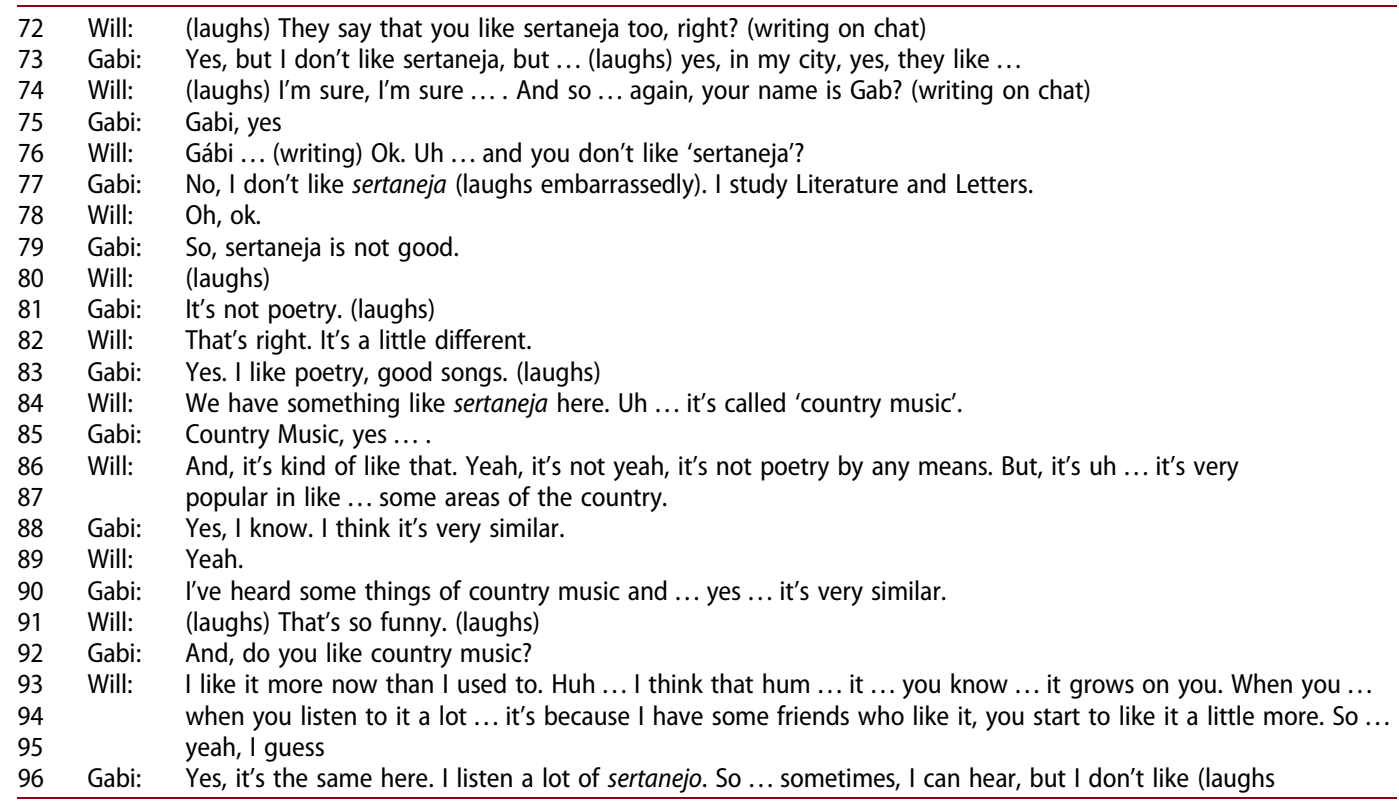




\section{(Excerpt 2: transcription of teletandem partners' multimodal interaction)}

Gabi is from the countryside of São Paulo State (Brazil). She used the word 'caipira' to explain the typical accent of people of her original region. This accent is characterized by the use of a retroflex ' $r$ ', and Gabi pronounces the word 'porta' (door) in order to give him an example.

Will shows that he understands her explanation when he associates 'caipira' with 'sertaneja' (country music): 'They say that you like sertaneja [country music], too, right?' (l. 72). Gabi says he is right, and she explains that the music style is frequently connected to the place where she was born.

However, her discourse suggests that for a person like her, enjoying 'sertaneja' is not 'appropriate': 'It's not poetry' and 'I like poetry, good songs'. Will's comment 'They say you like sertaneja ...' may imply 'You like this kind of music, because you are a country/farm girl, right?'. Trying to reduce his embarrassment at the difference of opinion, Will acknowledges the fact that country music is a 'little different' (I. 82) from poetry. He also compares Brazilian country songs with popular American country music.

The excerpt above evokes the dimension of culture as contested, because some values and beliefs from both the American and the Brazilian partners are clearly opposed by their interlocutor. Gaby contests her being associated with country music just for the fact of being born in an area of Brazil where people frequently listen to this type of music. Will, in turn, seems uncomfortable in showing his feelings about country music to Gabi. A sense of unease can be noticed in the conversation, because Gabi seems to exercise some sort of tacit power over Will's opinion regarding country music. This (somewhat tense) power relationship emerges from the fact that the Brazilian partner refuses to have country music projected on to her musical preferences only because of her origins. Her argument is that her language and literature studies distance her from country songs and have familiarized her with what she considers 'good music and poetry'. As she refutes her partner's association of her with country music, Gabi expresses a value judgement. In turn, Will's association could very well have been expressed either to please Gabi or to express closeness, by showing off his knowledge of her region's musical style.

When Will makes the generalization that people from the country like country songs, he gives us evidence of culture as relative. As mentioned earlier, this facet of culture is common in interactions between people from different cultures. Because of this tendency to oversimplification and generalization (based on pre-existing or sedimented concepts of other cultures), partners and mediators should interpret the information exchanged in teletandem sessions as belonging to the realm of the individual. Therefore, such information may be variable and multiple (culture as individual).

Gabi's value judgement is corroborated by the excerpt bellow, in which she seems to approve other Brazilian singers (not sertanejos) mentioned by Will. This excerpt was translated into English.

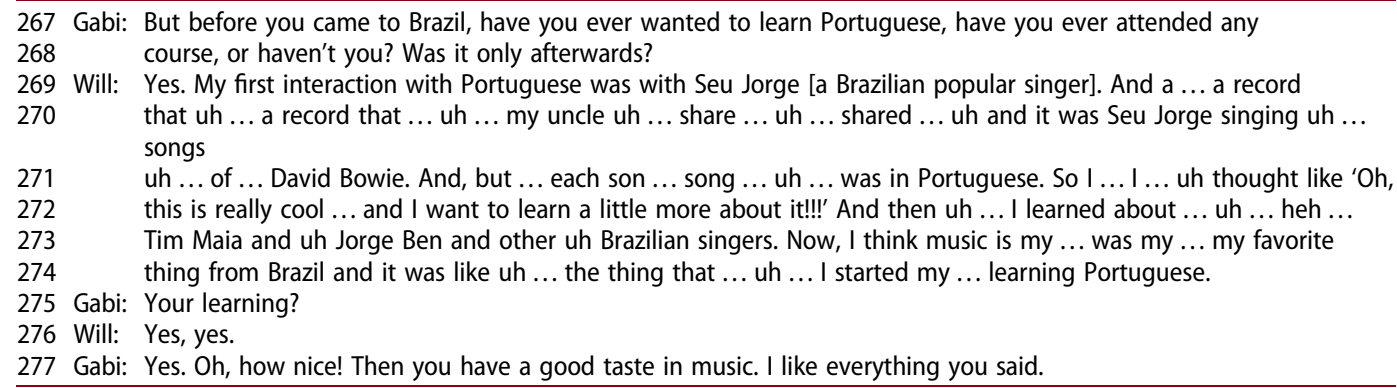

\section{Excerpt 3: transcription of teletandem partners' multimodal interaction}

In excerpt 3, Gabi clarifies what she understands by 'good music and poetry' and concludes that, if Will appreciates the singers he has mentioned, he has 'good taste in music' (I. 278). The conversation goes on and they keep mentioning more musicians. It is therefore apparent that culture as group membership can be evoked in this CRE as long as, after contesting each other's music preferences (concerning country music), Gabi and Will agree upon what they consider to be 'good music'. 
In the first three excerpts, we perceive the multiple dimensions of culture being simultaneously evoked. The generalization made by Will about 'people from the countryside' or about the ones 'who like country music' (or 'caipiras' according to Gabi's words) is related to Will's appropriated and sedimented construct (Miller 2012, 88) of this particular culture. This corroborates the idea that the foreign language learner is not a blank slate. As a foreign language learner, Will also carries systems of values and beliefs that have been with him almost since birth (culture as elemental). The teletandem interaction gives him a different perspective on the music preferences of a certain group of people when Gabi refuses to approve of sertanejo style and says instead that she appreciates 'good music', like her colleagues (culture as group membership).

In the excerpt below, Gabi introduces a new topic of debate: the partner's impressions of the South and the North of the United States.

150 Gabi: Ok. Ok. Do you like the South of the country?

151 Will: Ah, yeah ... I think it's ... you know ... it's different, it's very different. Specially ... I uh ... I'm from the North,

so it's ... you know ... the culture is very different in the South, but ... I think that ... after a while, you start to like it. They ... like Old (?) and they ... in the music and they like to have a good time. So, that's always fun.

Gabi: Ok. Ok. And you, in the North, you are more quiet?

Will: Hum ... l'd say ... it's a different kind of quiet. We don't uh ... we don't listen to country music for one thing. Gabi: (laughs)

Will: But um ... we uh ... it's not as laid back, I guess, I mean, as relaxed ... so the people are always busy, busy, busy working working working, whereas in the South they ... they like to relax a little more, they ... you know, and speak slowly and stuff like that.

Gabi: Huh ... ok, ok. So you are like us. Speak slower, more quiet, more relaxed, I think.

Will: In Brazil? Yeah, that sounds...

Gabi: In Brazil, yes. In [name of her hometown].

Will: In [name of her hometown]. But in São Paulo, não?

Gabi: Não! São Paulo, não! São Paulo they are all crazy. Absolutely crazy, yes!

Will: Yeah, that's like New York, yeah. São Paulo is like New York.

Gabi: And do you know New York ... very well?

Will: Hum ... I spent the Summer, this last Summer, like ... pretty close to the city ... not in it, but uh ... I've got to know it a lot better, yeah.

Gabi: I think uh ... when I watch television, because I don't know the United States, but I think New York is exactly like São Paulo.

Will: $\quad$ Yeah, I think so. Like, very big, very busy uh ... yeah ... very crazy.

Gabi: I don't want to know New York, just other parts of the United States, I think.

\section{Excerpt 4: transcription of teletandem partners' multimodal interaction}

Through the development of this new topic in the teletandem interaction (North and South), we can identify the dimensions of culture as elemental, as relative and also as group membership. The first one is due to the analogy between the South of the United States and the city where Gabi is from (in the countryside of São Paulo State). Both regions are described as known by their 'more relaxed people', with their 'slow speech' (I. 157-160), which are shared preconceptions that constitute a historical framework about people who live in those places.

The same analogical process is settled between the cities of São Paulo and New York, as metropolitan spaces in which social life is defined as 'crazy' and 'busy', which reinforces the evidence of culture as elemental identified in this excerpt. This is because, as Levy (2007) argues, this dimension of culture is related to systems of values and beliefs that are constructed from the moment we are born, through contact with people with whom we learn and share experiences and discourses.

Simultaneously, the same analogies between the South of the United States and Gabi's hometown also evoke the understanding of culture as relative, because during the teletandem interaction they make explicit comparisons between these two geographically distant places, identifying their similarities and making generalizations about them.

The analysis of teletandem interactions has shown that partners try to find things in common between them, especially with regard to social practices and lifestyles. Thus, the last identified dimension in this excerpt is culture as group membership. When Gabi says 'So you are like us' (I. 160), she discursively includes her partner, Will, in the same social group into which she simultaneously includes herself: people who live in the countryside. It is interesting to observe that Gabi in fact 
acknowledges that people from her hometown have those characteristics and so does she, since she uses the pronoun 'us'. In contrast to her refusal to endorse sertaneja music (excerpt 1), in this excerpt Gabi seems to belong to this group of people.

In the excerpt below, Gabi shares her experience as an exchange student in Portugal. During this section of the transcription, some of the most common stereotypes about Brazilian people are reinforced, as well as, simultaneously, some Brazilian pre-conceived representations of Portuguese people.

216 Will: And, what about the people? Were they ... like, you know, compared to Brazilians. I'm sure it's very

217 different too.

218 Gabi: Yes, yes. Hum ... Brazilians are very friendly. All ... but ... no ... not all the Brazilians, but most of it.

219 Will: Yeah.

220 Gabi: And, they like to hug ... [Mediator advises to change languages in the teletandem session and from this

221 point on the interaction was translated into English]. oh, yes ... I think we can speak in Portuguese language now

222 Will: Ok. No.

223 Gabi: Is it ok?

224 Will: Yes, it is. And what about the other differences ... uh ... in Portugal against Brazil?

225 Gabi: Yes, Portuguese people are much more distant, more ... do you understand? colder, they are not as 226 affectionate as Brazilian people. Yes

\section{Excerpt 5: transcription of teletandem partners' multimodal interaction}

The shared stereotypes about Brazilian people, as 'friendly' (I. 218) and affectionate (I. 220) demonstrate that there are similarities between Will's and Gabi's systems of beliefs.

Moreover, when Will says that he is 'sure' that people from Brazil and Portugal are different (I. 216217) he provides evidence that he shares with Gabi a similar frame of reference about Brazilian people in relation to Portuguese people, which triggers the dimension of culture as elemental.

Gabi's representations of Portuguese people are very different from (and even opposite to) the partner's shared beliefs about Brazilians. Will reinforces this opposition between Brazil and Portugal when he chooses the contrastive word against (I. 224) in order to ask about more differences between these two countries.

It's important to emphasize that Gabi's perception of Portuguese people is based on her own experience as an exchange student in Portugal, which leads us to evoke Levy's dimension of culture as individual.

As we observed in analysing the excerpts above, different dimensions of culture can be recognized when teletandem partners focus their dialogue on cultural aspects of each other's lived experiences. The identification of these different dimensions in a CRE demonstrates the multifaceted nature of the concept of culture that emerges when the participants discursively approach the cultural dimension of their representations and lived experiences during their multimodal interaction and, as a result, it legitimizes the theoretical choices we've made to guide the reflections concerning the present research scope.

\section{Conclusion}

The conception of culture as entangled intermixed realities, different from isolated spheres (Welsch 1999), and so with different facets, as exemplified by Levy (2007), seems a useful pedagogical and reflection-provoking construct for understanding the complexity of the cultural dimension of the teletandem context. In addition, the application of Levy's multidimensional understanding of culture to the analysis of CREs can offer teachers an effective epistemological base and methodological framework for grappling with the complexities of cultural issues that are bound to arise in multimodal online intercultural communication (such as teletandem). Both this concept and its application (theory and practice) may be particularly necessary in a time when learning languages and sharing cultural ideas through collaboration mediated by new multimodal interactional technologies tend to be part of our social reality. This is the case when we seek autonomous learning opportunities through teletandem. 
Finally, all the aspects of interactive exchanges among people from different parts of the world have a decisive impact on how we think about current learning and teaching. In this paper we identify culture-related episodes in teletandem interactions. We then attempt to relate them to the multiple dimensions and possibilities of interpretation about what can be understood as culture by teletandem partners. We believe this to be useful to a foreign language pedagogy of the twentyfirst century that adopts technology, particularly when teachers are called upon to act as mediators between students' learning processes and the multiple aspects of language, culture and relationships of power during virtual intercultural contact.

Our data show that the partners share their interpretations of lived experiences in their own and the partner's cultures. This is different from the traditional language teaching realities in which culture is frequently taught as a classroom subject. Both Will and Gabi bring expectations and personal interpretations of their partner's culture.

Nowadays, technologies offer a variety of possibilities of online, multimodal and intercultural communication to teaching and learning foreign languages (Goodfellow and Lamy 2009; Kramsch 1998, 2009). Sharing conversation through the exchange of ideas and life experiences between people of different nationalities and languages is now possible through these technologies. The challenge for foreign language educators now is how to deal with the multiple cultural differences offered by these intercultural contacts in educational ways. Learning foreign languages in teletandem engenders many possibilities of understanding culture in its various dimensions (Levy 2007). Regarding the pedagogical dimension of teletandem interactions, if teachers are appropriately prepared to mediate their students' teletandem sessions, this mode of online learning in tandem will prove to be efficient.

Finally, this case study is limited to the analysis of a single teletandem interaction. Since Gabi was a substitute for Will's partner and they were in contact for the first time, it would be interesting to study CREs in teletandem interactions between students who have been partners for a longer period of time. Further research on the vast institutionalized teletandem corpus (and other telecollaborative projects) may enable us to do this. In our context, we approached the complexity of the concept of culture by identifying the five perspectives offered on it by Levy (2007). Despite the limitations of our study, we hope it can inspire new possibilities of research into the cultural dimension of telecollaboration projects and bring further contributions to the understanding of cultural exchange and cultural learning within autonomous online and multimodal contexts.

\section{Notes}

1. See projects eTandem Europa (http://www.slf.ruhr-uni-bochum.de/etandem/etproj-en.html); eTandem Learning (http://www.cla.unipd.it/cetest-firstpage/autoapprendimento/tandem-learning/en-etandem/), Lingalog (http:// lingalog.net/dokuwiki/), INTENT[1] - Integrating Telecollaborative Networks into Foreign Language Higher Education (http://www.uni-collaboration.eu/), TILA[1] - Telecollaboration for Intercultural Language Acquisition (http://www. tilaproject.eu/moodle/), Tandem Exchange (https://www.tandemexchange.com/pt/).

2. See Telles (2006) and the website www.teletandembrasil.org.

3. See Telles (2011) and the website http://teletandemetransculturalidade.weebly.com/.

4. Language-related episodes have been defined as 'any part of a dialogue in which language students talk about the language they are producing, question their language use, or correct themselves or others' (Swain and Lapkin 1998, 326).

5. The participants' names are fictitious to preserve their identity.

\section{Disclosure statement}

No potential conflict of interest was reported by the authors.

\section{Notes on contributors}

Maisa A. Zakir earned a BA in Languages and Literatures, a MA in Education at UNESP (Universidade Estadual Paulista) in Brazil and a Ph.D. in Language Studies at the same university. She has experience in teaching languages in Brazil and 
abroad. She has worked as a Fulbright Teaching Assistant of Portuguese at the University of Miami and as a Portuguese Professor at Middlebury College, USA. She has also developed research activities at Unisalento, in Italy. Her research interests include language and culture learning in telecollaborative contexts and language teachers' education. Her recent publications include a book chapter on reading practices (2011), three papers on the teletandem context (2012, 2013 and 2015) and a paper on language teachers' education and discourse analysis (2013) in peer-reviewed journals. She was a member of the organizing committee of the I INFLIT Conference, which was held in Miami Feb. 27-Mar.1 2014.

Ludmila B. A. Funo earned a MA and a Ph.D. in Language Studies at UNESP/ Ibilce. Her research activities are about learning languages, culture and teacher's education in teletandem, an online multimodal collaborative learning environment. She has worked as PFL and culture professor for Flagship Programme at UNESP/lbilce (2013 and 2014). Her recent publications include three papers about Teletandem (2011, 2013 and 2015), a book chapter about tutors' didactic approach in virtual learning environments (2012).

João A. Telles has a Ph.D. in Educational Linguistics from OISE - Ontario Institute for Studies in Education - University of Toronto, Canada, and an MA in Applied Linguistics from the Catholic University of São Paulo, Brazil. He has developed post-doctorate research at Universitè Charles- de-Gaulle, Lille III, France. He was a visiting professor at IDEC - Institute for International Development and Cooperation, University of Hiroshima, Japan, and at Georgetown University, USA. Currently, he is associate professor of Foreign Language Teaching Practicum from the Department of Education, UNESP Universidade Estadual Paulista at Assis. He is the coordinator of Project Teletandem Brasil with research focus on the roles of video images in the interactions between Teletandem pairs. He has published numerous articles in the field. In 2009 he organized two books, one on teletandem and one on foreign language teachers' education.

\section{References}

Belz, J. A. 2003. "From The Special Issue Editor." Language Learning and Technology 7 (2): 2-5. Accessed May $25,2011$. http://lt.msu.edu/vol7num2/speced.html.

Brammerts, H. 2003. "Autonomous Language Learning in Tandem: The Development of a Concept." In Autonomous Language Learning in Tandem, edited by T. Lewis and L. Walker, 27-36. Sheffield: Academy Electronic.

Byram, M. 2000. "Assessing Intercultural Competence in Language Teaching." Sprogforum, 18 (6): 8-13. Accessed June 27, 2014. http://inet.dpb.dpu.dk/infodok/sprogforum/Espr18/byram.html.

Cavalari, S. M. S. 2009. "A autoavaliação em um contexto de ensino-aprendizagem de línguas em tandem via chat." PhD diss., Instituto de Biociências, Letras e Ciências Exatas, Universidade Estadual Paulista, São José do Rio Preto, São Paulo, Brazil.

Council of Europe. 2001. Common European Framework of Reference for Languages: Learning, Teaching, Assessment. Cambridge: Cambridge University Press. Accessed October 13, 2013. http://www.coe.int/t/dg4/linguistic/source/ framework_en.pdf.

Deardorff, D. K. 2004. "Internationalization: In Search of Intercultural Competence." International Educator 13 (2): $13-15$.

Dooly, M., and R. O'Dowd. 2012. Researching Online Foreign Language Interaction and Exchange: Theories, Methods and Challenges. Bern: Peter Lang.

Furtoso, V. A. B. 2011. "Desempenho oral em português para falantes de outras línguas: da avaliação à aprendizagem de línguas estrangeiras em contexto online." PhD diss., Instituto de Biociências, Letras e Ciências Exatas, Universidade Estadual Paulista, São José do Rio Preto, São Paulo, Brazil.

de Garcia, D. N. M. 2010. "Teletandem: Acordos e negociações entre os pares." PhD diss., Instituto de Biociências, Letras e Ciências Exatas, Universidade Estadual Paulista, São José do Rio Preto, São Paulo, Brazil.

Giroux, H. A. 1988. Teachers As Intellectuals: Towards A Critical Pedagogy of Learning. Granby, MA: Bergin and Garvey.

Goodfellow, R., and M.-N. Lamy. 2009. Learning Cultures in Online Education. London: Continuum.

Guest, M. 2002. "A Critical 'Checkbook' for Culture Teaching and Learning." ELT Journal 56 (2): 154-161.

Hinkel, E. 1996. "When in Rome: Evaluations of L2 Pragmalinguistic Behaviours." Journal of Pragmatics 26 (1): 51-70.

Kaneoya, M. L. C. K. 2008. "A formação inicial de professoras de línguas para/em contexto mediado pelo computador (teletandem): Um diálogo entre crenças, discurso e reflexão profissional." PhD diss. Instituto de Biociências, Letras e Ciências Exatas, Universidade Estadual Paulista, São José do Rio Preto, São Paulo, Brazil.

Kramsch, C. 1998. Language and Culture. Oxford: Oxford University Press.

Kramsch, C. 2009. "Third Culture and Language Education." In Contemporary Applied Linguistics: Volume One Language Teaching and Learning, edited by L. Wei and V. Cook, 233-254. London: Continuum.

Kramsch, C., and M. Uryo. 2014. "Intercultural Contact, Hybridity, and Third Space." In The Routledge Handbook of Language and Intercultural Communication, edited by J. Jackson, 211-225. New York: Routledge.

Kumaravadivelu, B. 2008. Cultural Globalization and Language Education. New Haven: Yale University Press.

Levy, M. 2007. "Culture, Culture Learning and New Technologies: Towards a Pedagogical Framework." Language Learning and Technology 11 (2): 104-127.

Lo Bianco, J., and C. Crozet. 2003. "Culture: Visible, Invisible and Multiple." In Teaching Invisible Culture: Classroom Practice and Theory, edited by J. Lo Bianco and C. Crozet, 11-38. Melbourne: Language Australia. 
Luvizari-Murad, L. H. 2011. "Aprendizagem de alemão e português via teletandem: um estudo com base na Teoria da Atividade." PhD diss., Instituto de Biociências, Letras e Ciências Exatas, Universidade Estadual Paulista, São José do Rio Preto, São Paulo, Brazil.

Marcuschi, L. A. 1986. Análise da conversação. São Paulo: Ática.

Miller, E. R. 2012. "Performativity Theory and Language Learning: Sedimenting, Appropriating, and Constituting Language and Subjectivity." Linguistics and Education 23 (1): 88-99.

National Standards in Foreign Language Education Project. 1996. Standards for Foreign Language Learning in the 21st Century. New York: Allen.

Pennycook, A. 2004. "Performativity and Language Studies." Critical Inquiry in Language Studies: An International Journal, 1 (1): 1-19.

Swain, M., and S. Lapkin. 1998. "Interaction and Second Language Learning: Two Adolescent French Immersion Students Working Together." Modern Language Journal 82 (3): 320-337.

Telles, J. A. 2006. "Projeto Teletandem Brasil: Línguas Estrangeiras para Todos - Ensinando e Aprendendo línguas estrangeiras in-tandem via MSN Messenger." Faculdade de Ciências e Letras de Assis, UNESP. Accessed September 2, 2010. http://www.teletandembrasil.org/site/docs/TELETANDEM_BRASIL_completo.pdf.

Telles, J. A. 2011. "Teletandem e Transculturalidade na interação on-line em línguas estrangeiras por webcam. Projeto de pesquisa financiado pela FAPESP." Accessed January 10, 2012. http://www.teletandembrasil.org/site/docs/ TELLESTRANSCULTPROJECT2011.pdf.

Telles, J. A. 2015. "Teletandem and Performativity." Revista Brasileira de Linguística Aplicada 15 (1): 1-30.

Telles, J. A., and M. J. Ferreira. 2011. "Teletandem: Possibilidades, dificuldades e abrangência de um projeto de comunicação online de PLE." Revista Horizontes em Linguistica Aplicada 9 (2): 79-104.

Vassallo, M. L. 2010. "Relações de poder em parcerias de teletandem.” PhD diss. Instituto de Biociências, Letras e Ciências Exatas, Universidade Estadual Paulista, São José do Rio Preto, São Paulo. Brazil; Università Ca'Foscari, Venezia, Italy.

Vassallo, M. L., and J. A. Telles. 2006. "Foreign Language Learning In-tandem: Part I - A Critical Review of Its Theoretical Principles." The ESPecialist 27 (1): 83-118.

Welsch, W. 1999. "Transculturality: The Puzzling Form of Cultures Today." In Space of Culture: City, Nation, World, edited by M. Featherstone and S. Lash, 194-213. London: Sage.

Zhu, J. 2012. "Weaving Language and Culture Together: The Process of Culture Learning in a Chinese as a Foreign Language Classroom." PhD diss., University of lowa. 